\title{
Geïntegreerde woordeboekgebruik van vakwoordeboeke vir aanleerders
}

\author{
Rufus H. Gouws, Departement Afrikaans en Nederlands, Universiteit \\ Stellenbosch, Stellenbosch, Republiek van Suid-Afrika (rhg@sun.ac.za)
}

Opsomming: Na 'n kort bespreking van aanleerderwoordeboeke en vakwoordeboeke word die fokus verskuif na vakwoordeboeke vir aanleerders. Die aanleerders wat hier ter sprake kom, kan aanleerders van 'n taal en/of aanleerders van 'n vakgebied wees. Albei hierdie tipes leerders word bespreek asook daardie vakwoordeboeke wat op aanleerders van sowel 'n taal as die vak gerig is. Met verwysing na die Suid-Afrikaanse leksikografiese omgewing en die opdrag van die nasionale woordeboekeenhede, word aangevoer dat vakwoordeboeke vir aanleerders ' $n$ wesenlike rol kan speel in die vestiging van ' $n$ woordeboekkultuur, maar ook die voorkoming van ' $n$ verdere leksikografies verlore generasie. Die konsep van geïntegreerde woordeboekgebruik word ingevoer en bespreek, met spesifieke verwysing na vakwoordeboeke vir aanleerders. Die voordeel van multiveldvakwoordeboeke vir aanleerders word aangetoon en aspekte van verskillende strukture van sulke woordeboeke word bespreek. Daar word aangevoer dat vir sulke woordeboeke 'n geamalgameerde sentrale teks verkieslik is bo 'n geamalgameerde makrostruktuur.

Sleutelwoorde: AANLEERDERWOORDEBOEK, GEAMALGAMEERDE MAKROSTRUKTUUR, GEAMALGAMEERDE SENTRALE TEKS, GEÏNTEGREERDE BINNETEKS, GEÏNTEGREERDE WOORDEBOEKGEBRUIK, KOGNITIEWE FUNKSIE, KOMMUNIKATIEWE FUNKSIE, LAAISTRUKTUUR, LEKSIKOGRAFIES VERLORE GENERASIE, LEKSIKOGRAFIESE FUNKSIES, MULTIVELDVAKWOORDEBOEK, SISTEMATIESE INLEIDING, TOEGANGSTRUKTUUR, VAKWOORDEBOEK, VAKWOORDEBOEK VIR AANLEERDERS, WOORDEBOEKGEBRUIKSPAKKET, WOORDEBOEKKULTUUR, WOORDEBOEKTIPOLOGIE

\begin{abstract}
Integrated Dictionary Use of Specialised Dictionaries for Learners. Following a brief discussion of learner's dictionaries and specialised dictionaries the attention is focused on specialised dictionaries for learners. The relevant learners targeted by these dictionaries can either be learners of a language or learners of a subject field. Both these types of learners are discussed as well as specialised dictionaries aimed at learners of both a language and the subject field. With reference to the South African lexicographic environment and the assignment of the national lexicographic units it is argued that specialised dictionaries for learners can play a significant role in establishing a dictionary culture but also in preventing a further lexicographically lost generation. The concept of integrated dictionary use is introduced and discussed, with specific reference to specialised dictionaries for learners. The benefits of multifield technical dictionaries for learners are indicated and aspects of different structures of these dictionaries are discussed. It is argued that for such dictionaries an amalgamated central text is preferred to an amalgamated macrostructure.
\end{abstract}


Keywords: ACCESS STRUCTURE, AMALGAMATED CENTRAL LIST, AMALGAMATED MACROSTRUCTURE, COGNITIVE FUNCTION, COMMUNICATIVE FUNCTION, DICTIONARY CULTURE, DICTIONARY TYPOLOGY, DICTIONARY USAGE PACKAGE, DRAWER STRUCTURE, INTEGRATED DICTIONARY USE, INTEGRATED INNER TEXT, LEARNER'S DICTIONARY, LEXICOGRAPHIC FUNCTIONS, LEXICOGRAPHICALLY LOST GENERATION, MULTIFIELD SPECIALISED DICTIONARY, SPECIALISED DICTIONARY, SPECIALISED DICTIONARY FOR LEARNERS, SYSTEMATIC INTRODUCTION

\section{Inleidend}

Een van die opvallende kenmerke van die hedendaagse leksikografie is die uitgebreide tipologiese verskeidenheid. In hierdie verband is dit belangrik om vertroud te wees met 'n aantal gevestigde onderskeidinge ten opsigte van die versameling woordeboeke. Een so 'n onderskeiding is dié tussen linguistiese en ensiklopediese woordeboeke. In linguistiese woordeboeke is die klem tradisioneel op die taalkundige kenmerke van woorde en in ensiklopediese woordeboeke eerder op die saak waarna die betrokke woord verwys. 'n Belangrike verdere tipologiese tweedeling is dié tussen woordeboeke wat met die algemene taal werk en daardie woordeboeke wat met die taal van spesifieke deelgebiede van die leksikon, byvoorbeeld vaktaal, werk. Dit lei tot die onderskeid tussen algemene en beperkte woordeboeke. Binne die kategorie beperkte woordeboeke bestaan 'n verskeidenheid subtipes waaraan daar nie nou aandag gegee word nie. Vakwoordeboeke, ook bekend as gespesialiseerde woordeboeke, is een so 'n subtipe wat vir die doel van hierdie artikel van belang is.

Woordeboeksoorte verteenwoordig nie afgeslote kategorieë nie en 'n oorvleueling van kenmerke kom algemeen voor. Hierdie soort oorvleueling geld tussen woordeboeke wat tot dieselfde breë kategorie behoort, byvoorbeeld die kategorie linguistiese woordeboeke, maar ook tussen woordeboeke wat tot verskillende breë kategorieë behoort, byvoorbeeld linguistiese woordeboeke wat sekere ensiklopediese kenmerke mag vertoon.

In die beplanning van enige woordeboek is dit belangrik dat bestaande woordeboektipologie nie die leksikograaf mag dwing om slegs kenmerke wat vir die bepaalde woordeboeksoort goedgekeur is in die beplande woordeboek in te sluit nie. Die vryheid moet bestaan en benut word om 'n woordeboek so saam te stel dat dit ook tipologies dit weerspieël wat die geïdentifiseerde teikengebruiker nodig het. Hartmann (1989) het dit duidelik gestel dat die samestelling van enige woordeboek voorafgegaan moet word deur ' $n$ indringende behoeftebepaling, en so ' $n$ behoeftebepaling is slegs moontlik na 'n ondubbelsinnige vasstelling van die teikengebruiker van die beplande woordeboek.

In navolging van Gouws (2007a) kan aangevoer word dat 'n formele tipologiese klassifikasie ' $n$ veel beperkter rol moet speel in besluite oor die aard en inhoud van nuwe woordeboeke. Na aanleiding van die gebruikersprofiel moet funksies van ' $n$ beplande woordeboek vasgestel word, en op grond van die vasgestelde funksies moet die inhoud en woordeboekstrukture bepaal word. Die 
aard van die woordeboek moet nie bepaal word deur 'n tipologiese klassifikasie wat vooraf gemaak word nie. Dit moet eerder volg as 'n reaksie ter beskrywing van die voltooide woordeboek. So 'n vasstelling wat eers gemaak word nadat die woordeboek voltooi is, kan nie altyd binne die bestaande tipologiese kategorieë plaasvind nie, en dit mag nodig wees dat ' $n$ nuwe en unieke tipologiese beskrywing vir ' $n$ gegewe woordeboek aangewend moet word. Een van die maniere waarop daar aan 'n te streng tipologiese klassifikasie ontsnap kan word, is deur die doelbewuste vermenging van kenmerke van verskillende en uiteenlopende woordeboeksoorte ter wille van die daarstelling van ' $n$ produk wat in 'n hoër mate geskik is vir die behoeftes van 'n gegewe gebruikersgroep. Die afgelope dekade het 'n daadwerklike vestiging gesien van hierdie beginsel van tipologiese hibridisering in die leksikografie. Hierdie benadering bied aan leksikograwe die moontlikheid om werklik gebruikergerigte woordeboeke te kan saamstel.

Bepaalde aspekte van onder meer tipologiese hibridisering word in hierdie artikel gebruik om voorstelle te maak vir 'n verbeterde aanbod en 'n nuwe soort gebruik van een tipe gespesialiseerde woordeboek, naamlik vakwoordeboeke wat vir aanleerders geskryf word.

\section{Die vestiging van bepaalde tipologiese kategorieë}

\subsection{Aanleerderwoordeboeke}

Aanleerderwoordeboeke kan gesien word as een van die duidelikste voorbeelde van die vestiging van ' $n$ nuwe tipologiese kategorie. ' $n$ Vroeë bydrae in hierdie verband was A.S. Hornby se Oxford Advanced Learner's Dictionary wat in 1948 verskyn het. Dit was egter veral sedert die sewentigerjare van die vorige eeu dat die ontwikkeling van hierdie kategorie op dreef gekom het, veral in die Britse woordeboekpraktyk. Die uiteindelike publikasie van die "Groot Vyf", dit is die eentalige Engelse aanleerderwoordeboeke van die uitgewers Oxford University Press, MacMillan, Longman, Cambridge University Press en Collins, was ' $n$ aanduiding van die verwesenliking van ' $n$ nuwe tipologiese kategorie. Naas die eentalige aanleerderwoordeboeke het daar algaande ook 'n verskeidenheid tweetalige aanleerderwoordeboeke verskyn. Daar was egter reeds vroeg 'n dispuut onder leksikograwe en taalkundiges oor watter tipe aanleerderwoordeboek, een- of tweetalig, die beste hulp aan 'n aanleerder kan bied (vergelyk in hierdie verband byvoorbeeld Atkins 1985). Van Britse Engelse aanleerderwoordeboeke het daar gereeld nuwe uitgawes verskyn sodat hierdie woordeboeke voortdurend 'n toonaangewende rol gespeel het, ondanks die toetrede van ander tale tot die aanleerderkategorie. Die vestiging en ontwikkeling van aanleerderwoordeboeke as tipologiese kategorie het ook ruimskoots aandag gekry in die teoretiese leksikografie. In talle navorsingspublikasies is daar aandag gegee aan 'n groot verskeidenheid aspekte van aanleerderleksikografie (vergelyk in hierdie verband onder meer Hausmann 1974, Cowie 1987, 
Otto 1989, Dolezal en McCreary 1999, Herbst en Popp 1999, Wiegand 1998; 2002 en Tarp 2008). Interessant in hierdie ontwikkeling is die uitvoerige aandag wat daar gewy is aan die verskyning van twee Duitse aanleerderwoordeboeke (vergelyk Wiegand 1998; 2002).

Aanleerderwoordeboeke word saamgestel met inagneming van die behoeftes en naslaanvaardighede van 'n duidelik en ondubbelsinnig omskrewe teikengebruiker. Eentalige aanleerderwoordeboeke is gerig op aanleerders wat die spesifieke taal wil aanleer maar maak nie noodwendig voorsiening vir die eiesoortige probleme wat uit die moedertaal van die voornemende gebruiker spruit nie. Daarteenoor is leksikograwe van tweetalige aanleerderwoordeboeke bewus van die spesifieke moedertaal van die tipiese teikengebruiker en kan hulle vir bepaalde probleme van die teikengebruiker op 'n meer gerigte manier voorsiening maak.

As tipologiese kategorie het aanleerderwoordeboeke 'n duidelike werklike doel. Daar is wel verskillende benaderings ten opsigte van die funksies van aanleerderwoordeboeke. In sommige gevalle is die teksresepsiefunksie oorheersend terwyl die teksproduksiefunksie in ander gevalle meer aandag kry. In baie aanleerderwoordeboeke word die kognitiewe funksie nie genoegsaam vervul nie maar in ander aanleerderwoordeboeke wel, veral waar die voornemende gebruikers kultuurgrense moet oorskry in hulle kennismaking met die taal wat aangeleer en die omgewing waar die betrokke taal gepraat word (vergelyk in hierdie verband die sterk kognitiewe funksie van die Kenkyusha Lighthouse Dictionary (Takebayashi en Kojima 19902), 'n tweetalige aanleerderwoordeboek met Engels en Japannees as taalpaar, maar wat uitsluitlik op die behoeftes van Japannese aanleerders van Engels afgestem is). Die werklike doel van 'n aanleerderwoordeboek is gerig op die vervulling van die somtotaal van die leksikografiese funksies wat vir die betrokke aanleerderwoordeboek geïdentifiseer is. Die aanleer van ' $n$ vreemde taal met die moontlikheid om tekste te kan verstaan en tekste te kan skep, asook om iets van die betrokke kultuur te leer, staan sentraal in die opdrag aan aanleerderwoordeboeke.

\section{$2.2 \quad$ Vakwoordeboeke}

Binne die woordeboektipologie bestaan 'n lang tradisie van woordeboeke wat daarop gerig is om die leksikon van 'n bepaalde vaktaal weer te gee, die sogenaamde vak- of gespesialiseerde woordeboeke. Soos in die geval van die algemene leksikografie het die praktyk van die maak van vakwoordeboeke ook in 'n preteoretiese milieu ontwikkel. Die ontwikkeling van die teoretiese leksikografie het aanvanklik veral teoretiese modelle geskep vir die daarstelling van algemene woordeboeke. Algaande het die teoretiese gesprek ook die vakleksikografie betrek (vergelyk in hierdie verband onder meer Schaeder en Bergenholtz 1984 en Bergenholtz en Tarp 1995).

Ook in die kategorie vakwoordeboek kan verskillende subtipes onderskei word. Daar is eerstens die algemene onderskeid tussen een- en twee- of meer- 
talige vakwoordeboeke. Bergenholtz en Tarp (1995) maak voorsiening vir belangrike verdere subtipologiese verdelings, onder meer die onderskeid tussen kultuurafhanklike en kultuuronafhanklike vakwoordeboeke, subveld-, enkelveld- en multiveldvakwoordeboeke, minimerende en maksimerende vakwoordeboeke en vakwoordeboeke vir die leek, die semideskundige en die deskundige. Hierdie verdelings is deurgaans gerig op 'n aanbod wat in 'n hoër mate die behoeftes van spesifieke gebruikers probeer bevredig.

Die aandag wat daar die afgelope twee dekades aan ontwikkelinge in die vakleksikografie gegee is en die teoretiese basis wat vanuit die metaleksikografie daarvoor ontwikkel is, is moontlik gemaak deur, maar is ook nogmaals 'n bewys van die status van die leksikografie as 'n onafhanklike dissipline wat nie meer ' $n$ onderafdeling van die taalkunde is nie (vergelyk in hierdie verband onder meer Tarp 2000, Wiegand 1998a en Gouws 2005). Die aanbod en bewerking in vakwoordeboeke is naamlik nie in die eerste plek gerig op die weergawe van taalkundige data nie. Dit gaan primêr om vakkundige inhoude. Wat belangrik is, is dat dieselfde teoretiese model waarvolgens die funksies, inhoud en struktuur van algemene woordeboeke bepaal word, ook van toepassing is in die beplanning van vakwoordeboeke. Die bestek van die algemene leksikografieteorie strek veel verder as net linguistiese woordeboeke. Die bewerking wat deur hierdie teorie moontlik gemaak word, is nie in die eerste plek gerig op die aanbod van taalkundige data nie maar wel op die aanbod van data wat volgens die aard en behoeftes van die geïdentifiseerde gebruikersprofiel nodig is.

Hierdie ontwikkeling in die algemene leksikografieteorie het ' $n$ bepaalde kentering in die aard van vakwoordeboeke meegebring. Dit is so dat talle vakwoordeboeke, veral vroeër, nie die leksikografiese behoeftes van hulle teikengebruikers bevredig het nie, onder meer omdat daar in die beplanning van die woordeboeke te min aandag gegee is aan die gebruikersprofiel of aan die teoretiese vereistes van produkte wat as woordeboeke geproduseer word. Talle ouer vakwoordeboeke is deur deskundiges op die betrokke vakgebied saamgestel sonder enige leksikograwe as medewerkers. Dit het dikwels gelei tot produkte wat vanuit 'n leksikografiese perspektief as onbevredigend beskou moet word, deurdat hulle, vanweë die beperkte bewerking, dikwels nie die grense van 'n blote woordelys oorskry het nie, meermale ook met die gee van slegs 'n enkele vertaalekwivalent. Deur die vakleksikografie as 'n formele deel van die algemene leksikografieteorie te betrek, word die beplanning van vakwoordeboeke in 'n veel hoër mate met inagneming van die betrokke teoretiese riglyne en die noodsaaklike betrokkenheid van leksikografiese kundiges gedoen. 'n Goeie voorbeeld uit die Suid-Afrikaanse leksikografiese omgewing is die huidige werk aan 'n nuwe uitgawe van die Woordeboek van Afrikaanse Geneeskundeterme (Lochner, in voorbereiding). In die beplanningsfase van die herbewerking het die Hoofredakteur, prof. Jan Lochner, die hulp van 'n teoretiese leksikograaf ingeroep om te verseker dat die uiteindelike woordeboek 'n voldoende teoretiese basis het. In die samestelling van die woordeboek word die Hoofredakteur bygestaan deur 'n span deskundiges uit die mediese vakgebied. Die betekenisverklarings van die terme word deur die deskundiges 
gedoen maar die manuskrip word dan aan 'n teoretiese leksikograaf voorgelê om te verseker dat die aanbod nie net vakkundig nie maar ook leksikografies in orde is. Samewerking tussen vakkundige en leksikograaf lei tot die daarstelling van 'n beter woordeboek.

\section{Die leksikografiese aanbod van vakterme}

Die ontwikkeling van die vakleksikografie op teoretiese vlak en die voortspruitende opbloei in die leksikografiese praktyk het gelei tot 'n opname en bewerking van 'n groot verskeidenheid vakterme uit 'n groot verskeidenheid vakgebiede in 'n groot verskeidenheid vakwoordeboeke. Desondanks moet ' $n$ vakwoordeboek steeds gesien word as 'n gesofistikeerde leksikografiese instrument wat blyke gee van 'n goed gevestigde en uitgebreide woordeboekversameling in die betrokke taalgemeenskap. Omdat vakwoordeboeke gerig is op die behoeftes van 'n relatiewe klein gebruikersgroep is hierdie woordeboeksoort van die latere toevoegings tot die leksikografiese versameling van ' $n$ bepaalde taal. Wanneer daar gepraat word oor die leksikografiese bewerking van vakterme, moet daar ' $n$ onderskeid gemaak word tussen die bewerking van sulke terme in vakwoordeboeke en die opname en bewerking daarvan in algemene woordeboeke. Die opname van vaktaalitems is naamlik nie beperk tot vakwoordeboeke nie. Veral in taalgemeenskappe met beperkte toegang tot leksikografiese bronne bestaan daar 'n goed gemotiveerde neiging ten gunste van multifunksionele hibridiese woordeboeke, en een aspek van hierdie hibridiese aard is juis die insluiting van items uit verskillende vakgebiede in woordeboeke wat primêr op die algemene leksikon gerig is.

Teenoor die uiters beperkte bewerking in talle vakwoordeboeke is die bewerking van vakterme in algemene woordeboeke gedoen in ooreenstemming met die kriteria wat gegeld het vir die bewerking van die ander items uit die algemene leksikon in daardie woordeboek. Vir die leek is daar gevolglik in 'n algemene woordeboek ' $n$ veel duideliker bewerking van die beperkte en diverse groep vakterme aangesien hierdie gespesialiseerde items op 'n niegespesialiseerde manier verklaar is. Dit geld veral in omgewings waar woordeboeke vir ontluikende tale saamgestel is en waar daardie tale nie oor ' $n$ verskeidenheid woordeboeksoorte beskik nie.

In Afrikaans het vroeëre dele van die WAT (vergelyk byvoorbeeld deel IV en V) talle vakterme opgeneem en van 'n redelik uitvoerige bewerking voorsien. Dit was veral in 'n tyd toe vakwoordeboeke nog nie vryelik beskikbaar was nie. Hierdie soort werkswyse is in elk geval nie vreemd in omvattende verklarende woordeboeke, die kategorie waartoe die WAT behoort, nie. Die omvang van die bewerking word dikwels bepaal deur die beskikbaarheid al dan nie van ander leksikografiese bronne waar inligting oor die betrokke vakterm verkry kan word.

Vakterme word egter ook in algemene woordeboeke van 'n beperkter omvang, byvoorbeeld hand- en standaardwoordeboeke, opgeneem. Hier word die 
opname egter bepaal deur die optrede in tipiese gespreksituasies waarby die teikengebruikers van die woordeboek betrokke is. Dit gaan veral om daardie vakterme wat voorkom in gesprekke tussen deskundige of semideskundige en leek. Die gewone taalgebruiker, ook in 'n taalgemeenskap met 'n gevestigde woordeboekkultuur, beskik nie noodwendig oor 'n vakwoordeboek met byvoorbeeld die mediese of die juridiese leksikon as teikengebied nie. In hulle daaglikse kommunikasie word gewone taalgebruikers, leke ten opsigte van byvoorbeeld die mediese of die juridiese terrein, van tyd tot tyd blootgestel aan vakterme uit hierdie gebiede, byvoorbeeld tydens 'n besoek aan 'n medikus of 'n prokureur. Die opname van 'n beperkte keuse vakterme in 'n algemene woordeboek is 'n standaardpraktyk. Die bewerking van sulke terme is gerig op die behoeftes en naslaanvaardighede van die teikengebruiker asook die funksies van die betrokke woordeboek, en nie op die behoeftes van die deskundige op die bepaalde vakgebied nie. Selfs in aanleerderwoordeboeke word vakterme van hierdie aard opgeneem, soos byvoorbeeld blyk uit die verklaring van die term tumour in COBUILD: "A tumour is a mass of diseased or abnormal cells that has grown in a person's or animal's body." So ' $n$ betekenisparafrase is verstaanbaar vir die leek en waarskynlik feitelik aanvaarbaar vir die deskundige. $\mathrm{Al}$ is die formulering eenvoudig, moet die wetenskaplike of gespesialiseerde waarde van ' $n$ term steeds op ' $n$ gepaste en ondubbelsinnige manier oorgedra word.

Die werklike probleem wanneer gebruikers hulle tot ' $n$ algemene woordeboek wend om 'n leksikografiese bewerking van vakterme te vind, is dat daar geen versekering is dat die spesifieke term in die betrokke woordeboek gevind sal word nie. Die keuse van vakterme vir opname in algemene woordeboeke is te beperk. Gebruikers moes dus daaraan gewoond raak dat vakterme in vakwoordeboeke nageslaan moet word. Dit het 'n bykomende las op die betrokke leksikograwe geplaas want raadpleging van woordeboeke deur gebruikers wat eerder algemene woordeboeke as vakwoordeboeke sou verkies, beteken dat sekere vakwoordeboeke nie net deskundiges en semideskundiges nie maar ook leke as teikengebruikers het. Die opstellers van vakwoordeboeke moet 'n baie duidelike beeld van hulle gebruikersprofiel hê: Is die teikengebruikersgroep deskundiges, semideskundiges en/of leke?

Alhoewel dit in hierdie artikel aanvaar word dat vakterme ook in algemene woordeboeke, insluitende algemene aanleerderwoordeboeke, opgeneem en bewerk word, is die fokus voortaan op die opname en bewerking van sulke leksikale items in vakwoordeboeke. Dit gaan egter nie oor alle vakwoordeboeke nie maar oor vakwoordeboeke wat op 'n bepaalde gebruikersgroep gerig is, soos in die hieropvolgende afdelings toegelig word.

\section{Vakwoordeboeke vir aanleerders}

Een van die tipologiese hibridiserings wat spruit uit ontwikkelinge in sowel die aanleerder- as die vakleksikografie is die skep van vakwoordeboeke vir aan- 
leerders (vergelyk Fuertes-Olivera en Arribas-Baño 2008 vir 'n bespreking van bepaalde aspekte van hierdie woordeboektipe). Ook hier word 'n verdere onderskeid gemaak, te wete tussen eentalige en tweetalige vakwoordeboeke vir aanleerders. Dit spreek vanself dat vakwoordeboeke ook op spesifieke gebruikersgroepe gerig moet wees en die woordeboekkonseptualiseringsplan moet met duidelike inagneming van die gebruikersprofiel saamgestel word.

In die tipologiese klassifikasies eentalige vakwoordeboek vir aanleerders en tweetalige vakwoordeboek vir aanleerders skep die deelterme eentalige vakwoordeboek en tweetalige vakwoordeboek nie begripsprobleme nie aangesien die gewone interpretasie van die terme eentalige, tweetalige en vakwoordeboek hier geld. Dit is weliswaar nie duidelik of dit om 'n sub-, enkel- of multiveldwoordeboek gaan, of dit 'n kultuurgebonde of niekultuurgebonde woordeboek is en of die woordeboek ' $n$ maksimerende of 'n minimerende benadering het nie. Die leksikografiese funksies van 'n woordeboek is ook nie duidelik uit die deelterme nie maar dit is kwessies wat alles in die betrokke woordeboekkonseptualiseringsplan uiteengesit word en wat nie uit die tipologiese klassifikasie hoef te blyk nie. Die deelterm aanleerder in die bogenoemde tipologiese klassifikasies is egter ' $n$ bron van groter onduidelikheid. Hierdie deelterm kan in die bepaalde klassifikasie geïnterpreteer word as sou dit na die aanleerder van ' $n$ taal of na die aanleerder van ' $n$ bepaalde vakgebied verwys. ' $n$ Vinnige oorsig oor bestaande vakwoordeboeke vir aanleerders wys dat albei hierdie lesings van die deelterm aanleerder wel voorkom. In alle gevalle is die betrokke woordeboek 'n vakwoordeboek wat aan die eise van dié tipologiese klassifikasie moet voldoen. As vakwoordeboek vir aanleerders het die spesifieke waarde van aanleerder 'n regstreekse invloed op wat ' $n$ voornemende gebruiker van so ' $n$ woordeboek te wagte kan wees. Waar ' $n$ bepaalde term 'n polisemiese leksikale item verteenwoordig, is dit noodsaaklik dat daar in die gebruik van daardie term ondubbelsinnig leiding gegee moet word oor watter lesing in die betrokke gebruiksomgewing geaktiveer word. Dit geld ook woordeboeke wat as vakwoordeboeke vir aanleerders of gespesialiseerde aanleerderwoordeboeke bekend staan.

Die Oxford Dictionary of Computing for Learners of English (Pyne en Tuck 1996) is 'n voorbeeld van 'n vakwoordeboek vir aanleerders waarin die fokus op die vakwoordeboekgebruiker is wat Engels as taal aanleer. Dit word duidelik in die voorwoord van hierdie woordeboek gestel. Hier gaan dit gevolglik om die eersgenoemde betekenisonderskeiding van die begrip aanleerder, naamlik die aanleerder van die betrokke taal, en waar so 'n woordeboek saamgestel word, vereis dit dat die gebruikersprofiel ook voorsiening vir die taalvermoë van die teikengebruiker moet maak. 'n Vakwoordeboek vir aanleerders waar die tweede betekenisonderskeiding van die begrip aanleerder, dit is die fokus op die aanleerder van die vakgebied, sentraal staan, is die SASOL Science and Technology Resource (Hartmann-Petersen 2001). In hierdie woordeboek wat leerders in die betrokke vakgebied inlei, is nie net die inhoud en aanbieding nie maar ook die metataal op die kennis-, kommunikasie- en opvoedkundige vlak 
van die teikengebruikers gerig. Die metataal en die aanbieding in hierdie woordeboek gee duidelik blyke van die opvoedkundige opdrag van die woordeboek.

Die beginsel van tipologiese hibridisering in die leksikografie laat ruimte vir talle moontlikhede, onder andere ook dat ' $n$ vakwoordeboek vir aanleerders op die aanleerder van die vak sowel as die aanleerder van die taal gerig kan wees. Dit kan lei tot ' $n$ veeldoelige produk wat in bepaalde gebruiksomgewings van groot waarde kan wees. Hierdie hibridisering vra egter 'n kundige aanpassing en integrasie van aanleerder- en vakwoordeboek. Daar moet ook deeglik besin word oor die behoefte aan sulke woordeboeke alvorens daar met die beplanning en samestelling begin word.

\section{5. 'n Kennismaking met enkele aspekte van bestaande vakwoordeboeke vir aanleerders}

Om woordeboeke, ook vakwoordeboeke vir aanleerders, tot effektiewe gebruiksinstrumente te verhef, is dit belangrik dat daar duidelikheid oor die leksikografiese funksies en die werklike doel van so 'n woordeboek moet wees. In hierdie verband kan daar gekyk word na die Ungarisch-Deutsches DeutschUngarisches Fachwörterbuch zur Rentenversicherung (Ildokó 2005). In die voorwoord van hierdie woordeboek word dit genoem dat die woordeboek saamgestel is met inagneming van bevindinge uit die metaleksikografie, pedagogiese leksikografie, tweetalige vakleksikografie asook navorsing in woordeboekgebruik. Dit word ook gestel dat hierdie woordeboek vir vertalers en tolke wat met Hongaars en Duits as taalpaar werk, bruikbaar wil wees in die spesifieke vakgebied wat hier ter sprake is. Dit word verder beskou as ' $n$ aanleerderwoordeboek vir inrigtings vir vertaling en tolking en waar Duits as gespesialiseerde vreemde taal onderrig word. Volgens die voorwoord is die woordeboek geskik as vakwoordeboek vir sowel teksproduksie as teksresepsie. Hier gaan dit duidelik om gebruikers wat nie net behoefte aan 'n vakwoordeboek het nie maar ook heelwat inligting oor die betrokke taalpaar benodig. Albei lesings van die begrip aanleerder geld vir hierdie woordeboek alhoewel die taalgerigte benadering nie net vir beginneraanleerders van waarde is nie maar veral ook vir gevorderde aanleerders.

Vergelykbaar hiermee is die reeds genoemde Oxford Dictionary of Computing for Learners of English. Synde 'n vakwoordeboek gaan dit in hierdie woordeboek uiteraard ook oor die bepaalde vakgebied maar veral oor aanleerders van Engels wat leiding nodig het met betrekking tot die vakgebied van rekenaars. Volgens die voorwoord is die woordeboek "especially for learners of English" bedoel. Die makrostrukturele keuse van die woordeboek bied 'n verteenwoordigende versameling items uit die betrokke vakgebied maar die bewerking van hierdie items fokus veral op die taalbehoeftes van die teikengebruikers. Dit 
blyk onder meer uit die volgende verduideliking in die voorwoord oor die bewerking van die lemmas:

Clear explanations of the grammar and meaning of words, along with authentic examples showing how words are really used make this dictionary a useful tool for helping to read, write, speak and understand the English used in computing today.

En in die gebruikersleiding:

If more detailed information on grammar or pronunciation is needed or if crossreferences, collocates, plurals, synonyms, parts of the verb or spelling and American variants are required they have all been convincingly placed together in the separate language column.

Die verwysing daarna dat hierdie woordeboek vir aanleerders van Engels bedoel is wat tot die middel- en gevorderde vlak behoort, wys nogmaals op die manier waarop daar hier met die begrip aanleerder gewerk word. Vakgebiedkennis is egter nie op die agtergrond nie. Die woordeboek is ' $n$ waardevolle naslaanwerk "for people who use computers and people who study computing" maar die vakgerigtheid vorm saam met die taalgerigtheid die fokus van die woordeboek. In die voorwoord word dit genoem dat die woordeboek steun op die gekombineerde kundigheid van kenners op die gebied van rekenaars en dié gemoeid met die onderrig van Engels as vreemde taal. Die aanleerders van die taal is hier nie die moedertaalsprekers nie maar wel die vreemdetaalsprekers.

Teenoor hierdie vakwoordeboeke vir aanleerders waar sowel vak as taal ' $n$ rol speel, staan die Duitse uitgewer Duden se vakwoordeboeke vir aanleerders in die reeks Schüler Duden. Hier gaan dit in 'n veel hoër mate om die vakgebied as om die taal. In die voorwoord van een van die woordeboeke in hierdie reeks, die Schüler Duden: Informatik (Claus en Schwill 1997) met die subtitel Ein Sachlexikon für die Schule ('n vakwoordeboek vir die skool), word dit duidelik gestel dat die woordeboek gerig is op leerders wat die veld van die informatika betree. ' $n$ Vergelykbare benadering geld in nog ' $n$ lid van hierdie reeks, die Schüler Duden: Die Musik (Kwiatkowski 1989). Geen verwysing word egter gemaak na enige poging om aanleerders met Duits te help nie.

Binne die Suid-Afrikaanse woordeboekomgewing kan vakwoordeboeke vir die aanleerder ' $n$ baie belangrike rol speel in sowel die gerigte daarstelling van vakkundige data vir aanleerders en hulp met die aanleer van taal as in die vestiging van ' $n$ woordeboekkultuur wat nie in isolasie gesien moet word nie maar deel van 'n omvattender kennis- en naslaankultuur uitmaak. Wat die aanleer van taal betref, hoef die begrip aanleerder nie uitsluitlik na gebruikers te verwys wat die betrokke taal as vreemde taal aanleer nie. Ook moedertaalsprekers wat in die aanleerfase is, kan binne die bestek van die term val. Leksikograwe sal goed doen deur aan die beplanning en samestelling van sulke woordeboeke oorweging te gee. 


\section{Woordeboeke en die Suid-Afrikaanse nasionale leksikografiese een- hede}

Met die vestiging van die Suid-Afrikaanse nasionale leksikografiese eenhede (NLE's) was dit nodig om 'n bestekopname te maak van watter woordeboeke in watter tale beskikbaar was. In 'n veel vroeëre opname (vergelyk Alberts en Mtintsilana 1988) is reeds bevind dat daar ' $n$ uitgebreide behoefte aan aanleerderwoordeboeke bestaan. Die begin van die NLE-era is daardeur gekenmerk dat sommige eenhede voortgegaan het met die werk aan bestaande woordeboekprojekte in die betrokke taal terwyl ander eenhede op soek was na 'n gepaste woordeboekprojek. Dit was al gou duidelik dat die wens van PanSAT, naamlik om 'n meerdelige omvattende verklarende woordeboek vir elk van die elf ampstale van Suid-Afrika daar te stel, nie spoedig verwesenlik sou word nie. In hierdie verband sê Gouws (2001: 77):

The compilation of a comprehensive monolingual dictionary presupposes a fully standardised language, a typological infrastructure in the given language as well as advanced lexicographic expertise and a sound metalexicographic basis. This is not the type of dictionary to be compiled as a first project. Although it should be the ultimate goal for every language to compile a comprehensive dictionary, it also has to be regarded as the lexicographic crown jewel, which is acquired once a network of smaller dictionaries has been completed.

Aan die opstel van kleiner woordeboeke en die vestiging van 'n tipologiese infrastruktuur sou die ontluikende standaardtale nog uitvoerig aandag moes gee in die keuse en uitvoering van woordeboekprojekte.

Dit is egter nie net die talle leemtes in die tipologiese infrastruktuur wat in ag geneem moet word in die leksikografiese beplanning van die NLE's en kommersiële woordeboekuitgewers nie. Die gebrek aan 'n woordeboekkultuur het 'n stremmende uitwerking op die potensiële gebruik van nuwe en bestaande woordeboeke. Die vestiging van 'n woordeboekkultuur mag ook nie geïsoleer word van die breër onderrig- en opvoedingstaak nie. Sedert die vestiging van die NLE's het enkele jare verloop. Sommige eenhede het die projekte voltooi waaraan daar vroeër reeds gewerk is, ander het kleinere nuwe projekte afgehandel terwyl die Buro van die WAT steeds suksesvol voortgaan met die omvattende projek waaraan daar sedert 1926 gewerk word. Vir al die eenhede was dit aanpassingsjare maar die werk wat tot dusver gedoen is, het die geleentheid geskep vir die leksikografiese basis wat nodig is vir verdere projekte. Alhoewel die samestelling van omvattende woordeboeke steeds die einddoel is, moet leksikograwe van die verskillende woordeboekeenhede bedag wees op die leksikografiese behoeftes van hulle onderskeie taalgemeenskappe. Iets wat tot dusver in ' $n$ te beperkte mate verwerklik is, is die vestiging van 'n woordeboekkultuur. Die skep van omvattende woordeboeke sal in hierdie verband nie die gewenste uitwerking hê nie. In verskeie taalgemeenskappe word SuidAfrika met 'n leksikografies verlore generasie gekonfronteer. Vir hierdie gene- 
rasie sal nuwe woordeboeke nie veel waarde hê nie. Wat wel binne die visie van die NLE's moet wees, is om te verseker dat die volgende generasies nie met dieselfde probleem te kampe het nie. Alhoewel die nasionale taalliggame van die onderskeie tale en onderskeie provinsies asook die kurrikulumbeplanners van die verskillende onderwysdepartemente ' $n$ wesenlike rol kan en moet speel in die vestiging van 'n woordeboekkultuur en die verwerwing van woordeboekvaardighede mag die rol van die NLE's in hierdie verband nie onderskat word nie. Juis hier kan vakwoordeboeke vir die aanleerder ' $n$ bydrae maak wat verder strek as die vestiging van 'n woordeboekkultuur.

\section{Geïntegreerde woordeboekgebruik}

Binne 'n opvoedkundige omgewing moet daar 'n onderskeid gemaak word tussen geïsoleerde en geïntegreerde woordeboekgebruik. In die eersgenoemde geval gaan dit om die toevallige gebruik van 'n woordeboek of die gebruik van 'n woordeboek binne ' $n$ bepaalde leeropdrag maar nie as ' $n$ formele deel van die leeropdrag nie. Daarteenoor impliseer geïntegreerde woordeboekgebruik dat dit 'n wesenlike deel van ' $n$ bepaalde leeropdrag is. Geïntegreerde woordeboekgebruik voorvereis die beplanning en samestelling van 'n bepaalde woordeboek as deel van 'n groter pakket van naslaanbronne. In die leksikografie bestaan daar reeds die gevestigde gebruik van sogenaamde woordeboekwerkboeke. Dit gaan om werkboeke met oefeninge wat die gebruiker help om óf 'n spesifieke woordeboek beter te kan gebruik óf om woordeboeknaslaanvaardighede oor die algemeen te verhoog. Wat die eersgenoemde aspek betref, is die Oxford Tweetalige Werkboek/Workbook (Hiles 2007) 'n goeie voorbeeld. Hierdie werkboek vergesel die Oxford Afrikaans-Engels English-Afrikaans Skoolwoordeboek School Dictionary (Louw 2007). Oefeninge in die werkboeke help die gebruiker om die stelsel van die betrokke woordeboek te verstaan en om die gehalte van die onttrekking van inligting te verhoog. Die oefeninge is so saamgestel dat die teikengebruikers van die betrokke woordeboek nie probleme met die begrip en benutting daarvan het nie. Wat algemene woordeboekwerkboeke betref (vergelyk byvoorbeeld Kipfer 1984), word woordeboekoefeninge in die werkboek ingesluit maar die werkboek is nie aan een spesifieke woordeboek gekoppel nie (vergelyk ook die bespreking van woordeboekwerkboeke in Stark 1990).

Die kombinasie van woordeboek plus werkboek is gerig op 'n beter ontsluiting van die betrokke woordeboek maar dit is nog nie ' $n$ voorbeeld van geïntegreerde woordeboekgebruik nie; daarvoor is die mede-optrede van ' $n$ verdere bron noodsaaklik. ' $n$ Tipiese voorbeeld van geïntegreerde woordeboekgebruik vind 'n mens waar ' $n$ woordeboek gekoppel is aan 'n bepaalde nieleksikografiese bron en die gebruik van die woordeboek onder meer daarop gerig is om die inhoud van die betrokke bron beter te ontsluit. Die mede-optrede van 'n woordeboekwerkboek kan 'n versterkende bonuswaarde hê maar is nie 'n verpligte komponent van die pakket nie. 
As ' $n$ voorbeeld van ' $n$ woordeboekgebruikspakket kan daar verwys word na die kombinasie handboek, woordeboek en woordeboekwerkboek wat 'n mens kry met betrekking tot die skoolhandboekreeks Nuwe Afrikaans sonder grense (Gouws en Latti 1996-2002), die woordeboek Nuwe woordeboek sonder grense (Gouws, Stark en Gouws 2004) en die gepaardgaande woordeboekwerkboeke Nuwe woordeboek sonder grense Werkboek (Gouws en Latti 2004-2005) waarvan vier vir die verskillende grade $(4,5,6$ en $7-9)$ voorsiening maak (vergelyk in hierdie verband ook die bespreking in Steyn 2004 en Steyn en Gouws 2005). Die handboekreeks is bedoel vir leerders met Afrikaans as addisionele taal en die betrokke woordeboek is saamgestel vir dieselfde teikengebruikersgroep, d.w.s. aanleerders van Afrikaans, en die doel is onder meer dat die woordeboek saam met die handboek gebruik word, ook ter verbetering van die aanleer van die werk wat in die handboek aan die orde kom. Die korpus wat vir die woordeboek gebruik is, is onder meer saamgestel uit studiemateriaal waarmee leerders wat die betrokke handboekreeks gebruik daagliks in aanraking kom. Die werkboek slaan ' $n$ brug tussen die woordeboek en die handboek met oefeninge waar oplossings vir probleme in die handboek in die woordeboek gevind moet word. In hulle omgang met Afrikaans as vak word die leerders bekendgestel aan die handboek asook die woordeboek en word hulle geleer om die woordeboek as praktiese gebruiksmiddel in te span in die oplossing van probleme uit die betrokke vakgebied wat in die handboek bespreek word. Hier lei geïntegreerde woordeboekgebruik tot groter insig in die betrokke vakgebied maar terselfdertyd tot die verwerwing van woordeboekgebruiksvaardighede en die vestiging van 'n woordeboekkultuur. Gegee die vroeëre verwysing na die verskillende waardes van die begrip aanleerder gaan dit hier om 'n woordeboek wat op die aanleerder van die taal gerig is maar die gebruik van die woordeboek is geïntegreer in die aanleer van die betrokke vakgebied. Nuwe woordeboek sonder grense is 'n algemene aanleerderwoordeboek vir leerders op skoolvlak maar maak ook voorsiening vir vakterminologie wat in die betrokke taalkurrikulum voorkom. Dit bied egter 'n wyer leksikale versameling as bloot die terminologie van 'n bepaalde vakgebied.

Hierdie soort benutting van 'n woordeboek kan 'n voorbeeld wees vir maniere waarop woordeboeke vir die Afrikatale saamgestel kan word sodat die gebruiker wat sowel taalaanleerder (ook moedertaalaanleerder) as vakaanleerder is daardeur bevoordeel word terwyl dit ook tot die vestiging van ' $n$ woordeboekkultuur lei. Sodoende kan die gevaar van verdere leksikografies verlore generasies bestry word.

\section{Vakwoordeboeke vir aanleerders in Suid-Afrika}

Die meeste vakwoordeboeke wat in die Suid-Afrikaanse tale geskryf word, het deskundiges en semideskundiges as teikengebruikers. Tot dusver is die vakleksikografie nog nie deur die NLE's bedryf nie. In die verlede was daar ook 'n meningsverskil daaroor of vakleksikografie binne die opdrag van die NLE's val 
al dan nie. Hierdie aspek word nie in hierdie artikel bespreek nie. Daar word van die standpunt uitgegaan dat dit die opdrag van die NLE's is om vir die leksikografiese versorging van hulle onderskeie tale verantwoordelikheid te neem, wat die beplanning van gespesialiseerde woordeboeke insluit.

Wat vakwoordeboeke betref, is dit reeds genoem dat 'n subtipologiese onderskeid gemaak word op grond van die kennisvlak van die geïdentifiseerde teikengebruiker van die woordeboek, naamlik vakwoordeboeke vir deskundiges, semideskundiges en leke. In aanleerderwoordeboeke word daar eweneens 'n subtipologiese onderskeid gemaak op grond van die kennisvlak van die gebruikers. Dit lei tot woordeboeke gerig op beginner-, medium- en gevorderdevlakgebruikers. In vakwoordeboeke vir aanleerders kan hierdie twee stelle gebruikerstipes tot 'n verskeidenheid moontlikhede lei, nl. beginnervlakdeskundige, beginnervlaksemideskundige, beginnervlakleek; mediumvlakdeskundige, mediumvlaksemideskundige, mediumvlakleek; gevorderdevlakdeskundige, gevorderdevlaksemideskundige, gevorderdevlakleek. Al hierdie gebruikersmoontlikhede word nie in hierdie artikel bespreek nie. Aandag word gegee aan die rol van vakwoordeboeke vir aanleerders op skoolvlak en veral op laerskoolvlak. Hierdie teikengebruikers is wat die vakgebied betref, leke, en wat die taal betref, op beginnertot mediumvlak. Die tipiese vakwoordeboek vir aanleerders wat hier te sake is, is dié wat gerig is op leke in die betrokke vakgebied en in die beginner- tot mediumfase van taalaanleer.

\section{9. 'n Geïntegreerde benadering en die skep van 'n woordeboekkultuur}

'n Opvallende verskynsel in veral die aanleerder- maar ook die vakwoordeboekversameling is dat hierdie woordeboeksoorte in 'n beperkte aantal tale saamgestel word. Albei tipes word as gesofistikeerde leksikografiese ondernemings beskou. Aanleerderwoordeboeke kom veral, alhoewel nie uitsluitlik nie, voor in daardie tale wat groot internasionale verkeerstale is. Vakwoordeboeke word in veel meer tale aangetref maar die samestelling van vakwoordeboeke voorveronderstel die bestaan van 'n gevestigde vakwoordeskat in die betrokke taal. Die beginsel van ' $n$ vakwoordeboek vir aanleerders waar dit om ' $n$ aanleerder van die vakgebied gaan, impliseer nie noodwendig dat dit ' $n$ taal behels wat ' $n$ terminologies leidende rol speel nie maar wel dat dit ' $n$ taal is waarin die vakterminologie bestaan. Vakwoordeboeke word egter ook gesien en gebruik as instrumente om die bepaalde vakterminologie te vestig. Soos reeds genoem, behoort die beplanning en samestelling van 'n vakwoordeboek 'n gesamentlike projek van vakkundige en leksikograaf te wees. Dit is nie 'n geleentheid vir die leksikograaf om terme te skep nie maar wel vir die vakkundige om sowel gevestigde as nuwe terme vir leksikografiese blootstelling en bewerking voor te lê. Die nege Afrikatale wat ampstale in Suid-Afrika is, is nog nie almal ten volle gestandaardiseer nie, soos blyk uit die talle voortgaande gesprekke oor byvoorbeeld ortografiese pre- en proskripsie. Ook die vakterminologie is nie grondig gevestig in al dié tale nie. Op hierdie gebied kan daar met reg van 'n 
ontluikende vakterminologie gepraat word. Om met vakwoordeboeke vir die deskundige en semideskundige te begin, kan in 'n hoë mate frustrerend wees aangesien talle terme in hierdie stadium nog ontbreek. Ook in hierdie opsig kan die inwerkingstelling van 'n benadering van geïntegreerde woordeboekgebruik veel daartoe bydra om die ontwikkeling van die ontluikende vakterminologie te bevorder. Vakwoordeboeke vir laerskoolleerders kan 'n ideale beginpunt wees. 'n Pakket bestaande uit handboek, woordeboek en dalk selfs ook woordeboekwerkboek kan vir die vroeë fases van leerarea-onderrig saamgestel word. Vir die leerders wat aan hierdie geïntegreerde woordeboekgebruik blootgestel word, kan daar voorsiening gemaak word vir 'n vergelykbare pakket in die daaropvolgende fase. Deur die loop van hulle skoolloopbaan kan geïntegreerde woordeboekgebruik 'n geïntegreerde deel van hulle opleiding wees. Algaande kan hulle in hulle woordeboekgebruik vorder na algemene woordeboeke.

Die NLE's, in samewerking met die onderskeie onderwysdepartemente en ten beste ook met bestaande uitgewersmaatskappye, kan hulle in die bemagtiging van hulle onderskeie taalgemeenskappe daarop toelê om vakwoordeboeke vir aanleerders te skryf. Deur 'n benadering van geïntegreerde woordeboekgebruik na te streef met die woordeboeke wat help om die handboek te ontsluit en, verkieslik, met 'n gepaardgaande woordeboekwerkboek wat leerders kan help met die verwerwing van woordeboekgebruiksvaardighede, kan die NLE's ' $n$ wesenlike rol speel in ' $n$ veelfasettige kennisvestiging. Vir woordeboeke wat ter wille van so 'n benadering van geïntegreerde woordeboekgebruik saamgestel word, is dit belangrik dat die leksikograwe indringend aandag gee aan die tersaaklike leksikografiese funksies. Vakwoordeboeke het primêr 'n kognitiewe funksie terwyl aanleerderwoordeboeke ook 'n sterk kommunikatiewe funksie het. 'n Vakwoordeboek vir aanleerders wat veral op die gebruiker as aanleerder van die vak gerig is, het 'n sterker kognitiewe funksie terwyl 'n sterker kommunikatiewe funksie geld in gevalle waar die woordeboek ook vir die aanleer van taal voorsiening maak. In 'n benadering van geïntegreerde woordeboekgebruik sal kognitiewe en kommunikatiewe funksies gelykwaardige aandag moet kry, en vir die kommunikatiewe funksies sal sowel teksproduksie as teksresepsie ter sake wees. Dit gaan om 'n polifunksionele woordeboek. Wat die kommunikatiewe funksie betref, speel teksresepsie al dan teksproduksie normaalweg 'n bepalende rol daarin of die woordeboek in die makrostrukturele keuse 'n maksimerende al dan 'n minimerende benadering volg. 'n Maksimerende benadering, dit wil sê waar die makrostrukturele keuse so uitvoerig moontlik is, is veral ter sake in die geval van teksresepsie. In die geval van teksproduksie is ' $n$ minimerende benadering, dit wil sê ' $n$ beperkter makrostrukturele keuse maar ' $n$ uitvoeriger mikrostrukturele bewerking, eerder die keuse. Waar albei kommunikatiewe funksies aanwesig is, moet 'n balans getref word tussen maksimerend en minimerend. In die geval van die voorgestelde vakwoordeboeke sal die behoeftes van die teikengebruikers bepalend wees. Aangesien dit ten opsigte van die vakgebied om leke gaan, is slegs 
'n beperkte makrostrukturele keuse nodig. Die gebruikers sal wel baat by ' $n$ uitvoerige mikrostrukturele bewerking van hierdie items, ook ter wille van die taalaanleerfunksie. Die metataal van hierdie bewerking moet versoenbaar wees met die taalvlak van die teikengebruikers.

In die beplanning van die voorgestelde vakwoordeboeke vir aanleerders is dit belangrik om kennis te neem van 'n bepaalde subtipologiese onderskeid wat Bergenholtz en Tarp (1995) maak, te wete dié tussen sub-, enkel- en multiveldwoordeboeke. Vir laerskoolleerders is subveldwoordeboeke nie so ter sake nie. Die ideaal is om enkelveldwoordeboeke vir elke afsonderlike leerarea te hê. Op pad na hierdie ideaal sou egter voorlopig multiveldwoordeboeke gebruik kon word waarin die leksikon van verwante leerareas gedek word.

\section{Aspekte van die struktuur van die voorgestelde vakwoordeboek vir aanleerders}

\section{1 'n Verskeidenheid aangepaste strukture}

Die algemene leksikografieteorie maak voorsiening vir 'n verskeidenheid woordeboekstrukture. In die woordeboekkonseptualiseringsplan van elke afsonderlike woordeboek is dit die taak van die leksikograaf om te besluit watter strukture vir die betrokke woordeboek ter sake is en hoe die algemene strukture ' $n$ woordeboekspesifieke aanpassing en toepassing moet kry. Dit geld ook vakwoordeboeke en aanleerderwoordeboeke, en waar dit om vakwoordeboeke vir aanleerders gaan, is ' $n$ verdere aanpassing nodig. Dit is belangrik dat die relevante strukture so ontwikkel moet word dat die leksikografiese funksies van die betrokke woordeboek daardeur vervul kan word. Gevolglik mag geen struktuur sonder meer op ' $n$ woordeboek afgedwing word nie. As dit gaan oor die aard van onder meer die dataverspreiding-, raam-, makro-, mikro-, toegangs- en adresseringstruktuur, is dit belangrik dat hierdie strukture telkens aangepas word met inagneming van die funksies van die woordeboek maar ook die gebruikersprofiel, en meer spesifiek die behoeftes en naslaanvaardighede van die potensiële teikengebruiker. Die beginsel van geïntegreerde woordeboekgebruik is nuut en die implikasies daarvan vir woordeboekstrukture is nog glad nie bespreek nie. Slegs enkele voorstelle met betrekking tot enkele struktuurtipes word vervolgens aan die hand gedoen. 'n Veel omvattender bespreking is nodig.

\section{2 'n Geamalgameerde sentrale teks versus 'n enkele geamalgameerde makrostruktuur}

Geïntegreerde woordeboekgebruik voorveronderstel die interaktiewe gebruik van minstens een woordeboek en minstens een ander bron. In die geval van vakwoordeboeke vir aanleerders is hierdie ander bron by voorkeur ' $n$ hand- 
boek of ander vorm van studiemateriaal vir die betrokke teikengebruikersgroep. Daar kan egter ook meer as een woordeboek en meer as een handboek of niewoordeboekbron wees. In die geval van 'n multiveldvakwoordeboek vir aanleerders in die laerskool sal daar waarskynlik nie een ooreenstemmende multiveldhandboek wees nie. Die beplanning van 'n multiveldvakwoordeboek vir geïntegreerde gebruik moet liefs so geskied dat handboeke vir soveel as moontlik van die vakke wat in die woordeboek aangebied word, as geïntegreerde woordeboekeksterne buitetekste betrek kan word. Die sentrale komponent van so 'n woordeboek kan óf 'n geamalgameerde sentrale teks, óf ' $n$ enkele geamalgameerde makrostruktuur wees (vergelyk Gouws en Leroyer 2009). In die geval van 'n geamalgameerde sentrale teks, dit is ' $n$ teks met ' $n$ laaistruktuur, sal elke vakgebied van die multiveldwoordeboek 'n afsonderlike en selfstandige teks in die sentrale komponent van die woordeboek wees, soos 'n reeks laaie binne die woordeboekstruktuur. As "groot teks" (vergelyk Kammerer en Wiegand 1998) bestaan 'n multiveldwoordeboek met 'n laaistruktuur uit opeenvolgende tekste wat elk 'n selfstandige enkelveldwoordeboek is waarin die terminologie van 'n gegewe vakgebied aangebied en bewerk word. Hierdie afsonderlike tekste is gelykwaardige komponente van die groot teks en almal tree as selfstandige binnetekste op, dit is die afsonderlike tekste in die sentrale komponent van ' $n$ woordeboek met 'n raamstruktuur, hetsy 'n volle hetsy ' $n$ halwe raam. Binnetekste waartussen daar deur middel van kruisverwysings verbande gelê word, staan as geïntegreerde binnetekste bekend. In 'n multiveldvakwoordeboek word geïntegreerde binnetekste veral aangetref waar dieselfde terme in meer as een vakgebied voorkom en daar dienooreenkomstige kruisverwysings verskyn. Tussen hierdie tekste bestaan daar dus 'n geïntegreerde verband.

Waar 'n multiveldwoordeboek 'n geamalgameerde makrostruktuur het, bestaan die sentrale komponente slegs uit een alfabeties geordende teks wat al die lemmata uit al die verskillende vakgebiede bevat. Vir elke lemma word daar per etiket aangedui tot watter veld of velde die betrokke term behoort. Vanuit sowel 'n sistematiese as 'n didaktiese oogpunt is 'n geamalgameerde sentrale teks, die laaistruktuur, aan te beveel bo 'n geamalgameerde makrostruktuur vir 'n multiveldvakwoordeboek vir aanleerders. Vir gebruikers bied die laaistruktuur vinnige toegang tot die lemmas wat vir ' $n$ bepaalde vakgebied verstrek word.

\subsection{Die dataverspreidingstruktuur}

In die beplanning van enige woordeboek moet daar uitvoerig aandag gegee word aan die dataverspreidingstruktuur (vergelyk in hierdie verband Bergenholtz en Tarp 1995 asook Bergenholtz, Tarp en Wiegand 1999). As 'n draer van tekstipes (vergelyk Kammerer en Wiegand 1998) bevat 'n woordeboek 'n verskeidenheid tekste wat in die sentrale komponent asook die voor- en agtertekste-afdelings, die sogenaamde buitetekste van die woordeboek aangebied word. Die beplanning van die dataverspreidingstruktuur is nie net op die sen- 
trale teks gerig nie maar ook op die voor- en agtertekste-afdelings wat aan leksikograwe 'n geleentheid verskaf om daardie data in 'n woordeboek aan te bied waarvoor die verstekartikel nie voorsiening maak nie. In sowel vak- as aanleerderwoordeboeke kan die buitetekste 'n wesenlike rol speel in die data-aanbod. In aanleerderwoordeboeke kan hulle onder meer gebruikers vertroud maak met die grammatiese stelsel van die taal wat aangeleer word, asook met bepaalde kultuurgebruike aangesien dit nie net oor die aanleer van 'n taal gaan nie maar ook oor die aanleer van 'n nuwe kultuur - iets wat binne die kognitiewe funksie van die woordeboek val. In vakwoordeboeke is daar talle aspekte van die vakgebied wat in buitetekste deur middel van byvoorbeeld tabelle weergegee kan word om die gebruiker te help met 'n beter verwerwing van kennis van die betrokke vakgebied (vergelyk in hierdie verband die buitetekste in die SASOL Science and Technology Resource). Woordeboeke van die toekoms behoort op ' $n$ vernuwende manier buitetekste te gebruik. Dit is belangrik dat die buitetekste ook geïntegreerd moet wees in die funksies van die woordeboek om sodoende ' $n$ transtekstuele benadering tot woordeboekfunksies te verseker (vergelyk Gouws 2007).

In die vakleksikografie word daar baie klem geplaas op die optrede van 'n sogenaamde sistematiese inleiding as een van die buitetekste van ' $n$ vakwoordeboek. Dit is 'n teks waarin 'n inleiding gegee word tot die vakgebied waarvan die terminologie in die betrokke woordeboek behandel word (vergelyk in hierdie verband byvoorbeeld die Encyclopedic Dictionary of Gene Technology (Kaufmann en Bergenholtz 1998)). As 'n geïntegreerde buiteteks (vergelyk Bergenholtz, Tarp en Wiegand 1999 en Bergenholtz en Nielsen 2006) word daar vanuit die sentrale teks van die woordeboek kruisverwysings na die sistematiese inleiding gemaak sodat gebruikers bykomende inligting kan onttrek. Dieselfde benadering word gevolg in die uitvoerige vakwoordeboek vir deskundiges en semideskundiges Fachwörterbuch zur Lexikographie und Wörterbuchforschung/Dictionary of Lexicography and Dictionary Research (Wiegand et al. 2009). Ook wat geïntegreerde buitetekste betref, sal baie van die data wat in sulke tekste in 'n vakwoordeboek vir aanleerders wat as geïsoleerde produk verskyn, aangebied word (vergelyk byvoorbeeld die SASOL Science and Technology Resource en sy buitetekste), nie deel van die vakwoordeboek se data-opdrag wees nie maar eerder binne die bestek van die handboek se opdrag val.

Waar 'n stelsel van geïntegreerde woordeboekgebruik gevolg word, is daar werklike gevolge vir die struktuur van die woordeboek. In die dataverspreidingstruktuur moet die leksikograaf die data wat reeds in die handboek verskyn, in ag neem. Dit bring mee dat so 'n woordeboek byvoorbeeld nie ' $n$ sistematiese inleiding hoef te hê nie; die handboek dien hierdie doel. Belangrik is dat daar dan vanuit die woordeboek regstreekse kruisverwysings na die handboek gemaak moet word om die bewerking van bepaalde terme in die woordeboek in 'n wyer besprekingskonteks te plaas. Terme wat in die handboek gebruik en in die woordeboek verklaar word, kan in die handboek gemerk word, byvoorbeeld deur dit in vet druk aan te bied. Sodoende sal gebruikers weet dat die pakket voorsiening maak vir 'n leksikografiese bewer- 
king van die betrokke terme. Die wisselwerking tussen hand- en woordeboek deur middel van kruisverwysings verhef die handboek tot 'n woordeboekeksterne geïntegreerde buiteteks.

Ten opsigte van die kognitiewe funksie kan die woordeboek wel aanvullend tot die handboek optree deur per geïntegreerde buitetekste voorsiening te maak vir relevante data wat nie in die handboek aangebied word nie. $\mathrm{Al}$ is die dataverspreidingstruktuur van ' $n$ beperkter omvang, is daar steeds ruimte vir 'n raamstruktuur. In hierdie verband is dit nogmaals nodig dat vakkundige en leksikograaf saam aan die inhoud van die woordeboek beplan.

\subsection{Die toegangstruktuur}

Die sukses van enige woordeboekraadplegingshandeling word in die eerste plek daardeur bepaal dat gebruikers toegang verkry tot die data waarna hulle soek. Daaruit kan inligting onttrek word ter bevrediging van die tersaaklike gebruikersbehoefte. Tans word in die metaleksikografie klem gelê op die omvattende toegangsproses wat veel meer as net die toegangstruktuur insluit (vergelyk in hierdie verband Bergenholtz en Gouws 2008). Die toegangsproses maak onder meer daarvoor voorsiening dat verskillende gebruikers verskillende toegangsroetes kan volg wat uiteenlopende beginpunte het. In die geval van geïntegreerde woordeboekgebruik kan die beginpunt van die toegangsproses van 'n gegewe woordeboekraadplegingshandeling byvoorbeeld in die teks van 'n woordeboekeksterne bron lê, soos die handboek wat as deel van die pakket aangebied word. In die beplanning van vakwoordeboeke vir aanleerders wat op geïntegreerde woordeboekgebruik gerig is, moet daar in die woordeboekkonseptualiseringsplan voorsiening gemaak word vir 'n verskeidenheid toegangsmoontlikhede; dit geld sowel die eksterne as die interne toegangsroetes.

Politoeganklikheid word daardeur in die hand gewerk dat data nie net via die makrostruktuurelement wat die gidselement van 'n bepaalde artikel is, bereik kan word nie. Kruisverwysings vanuit 'n geïntegreerde buiteteks of woordeboekeksterne teks skep bykomende toegangsgeleenthede. Waar so ' $n$ vakwoordeboek 'n raamstruktuur vertoon, kan die agtertekste-afdeling een of meer buitetekste insluit wat alfabetiese registers is van die terme wat vir die verskillende vakgebiede in die multiveldwoordeboek aangebied word. 'n Termregister kan vir elke afsonderlike vakgebied verskaf word. Sodoende word die gehalte van die woordeboek as politoeganklike bron nog verder verhoog.

Belangrik in die gebruik van 'n multiveldvakwoordeboek vir aanleerders, veral waar geïntegreerde woordeboekgebruik nagestreef word, is dat die leksikograaf vertroud moet wees met verskillende moontlikhede in die preraadplegingsfase van die toegangsproses (vergelyk Bergenholtz en Gouws 2008). 


\section{Die medium van vakwoordeboeke vir aanleerders}

'n Besluit wat ' $n$ leksikograaf reeds in die fase van die woordeboekkonseptualiseringsplan moet neem, geld die medium waarin die woordeboek aangebied word, naamlik in gedrukte en/of elektroniese formaat. In die laasgenoemde geval is 'n verdere besluit of dit as 'n CD ROM-weergawe of as internetweergawe beskikbaar moet wees. Wat die keuse van die medium betref, speel die gebruikersprofiel asook die gebruik- en gebruikersituasie 'n belangrike rol. Hierdie aspek word nie in hierdie artikel uitvoerig bespreek nie.

Wat die situasie van aanleerders in die Suid-Afrikaanse skoleomgewing betref, mag leksikograwe nie te gou uitsluitlik op gedrukte woordeboeke terugval nie. Talle skole, ook vir leerders uit die voorheen benadeelde groepe, het redelike toegang tot rekenaargeriewe en die internet. Vakwoordeboeke vir aanleerders moet op die huidige situasie maar ook op die onmiddellike toekoms gerig wees. Dit sal goed wees indien hierdie bronne in sowel elektroniese as gedrukte formaat beskikbaar kan wees. Dit geld nie net die woordeboeke nie maar die volle pakket wat die geïntegreerde gebruik moontlik maak.

'n Groot voordeel van 'n vakwoordeboek wat in die elektroniese medium beskikbaar is, veral as internetwoordeboek, is die politoeganklikheid daarvan, die aktiewe benutting van kruisverwysings asook die maklike toegang tot inskrywings wat nie lemmastatus het nie. Dit is aspekte waaraan leksikograwe indringend in hulle beplanning aandag moet gee.

\section{Ten slotte}

Vakwoordeboeke vir aanleerders is 'n woordeboektipe wat in die Suid-Afrikaanse woordeboekgebruiksomgewing met vrug benut kan word. Die bereiking van die werklike doel van die betrokke woordeboeke is belangrik maar sulke woordeboeke kan ook 'n beter woordeboekkultuur help vestig. Die geïntegreerde gebruik van hierdie woordeboeksoort kan daadwerklik bydra tot die verbetering van kennisoordrag en woordeboekgebruiksvaardighede. Dit kan 'n aandeel hê in die voorkoming van verdere leksikografies verlore generasies.

\section{Bibliografie}

Alberts, M. en P. Mtintsilana. 1988. Leksikografiese ontleding van Afrikaans en Afrikatale-leksikons. RGN-verslag LEXI-2. Pretoria: Raad vir Geesteswetenskaplike Navorsing.

Atkins, B.T. 1985. Monolingual and Bilingual Learners' Dictionaries: A Comparison. Ilson, R. (Red.). 1985. Dictionaries, Lexicography and Language Learning: 15-24. Oxford: Pergamon Press.

Bergenholtz, H. en R.H. Gouws. 2008. The Access Process for Fixed Expressions. Lexicographica 23: 236-260.

Bergenholtz, H. en S. Nielsen. 2006 Subject-field Components as Integrated Parts of LSP Dictionaries. Terminology 2(12): 281-303. 
Bergenholtz, H. en S. Tarp (Reds.). 1995. Manual of Specialised Lexicography: The Preparation of Specialised Dictionaries. Amsterdam: John Benjamins.

Bergenholtz, H., S. Tarp en H.E. Wiegand. 1999. Datendistributionsstrukturen, Makro- und Mikrostrukturen in neueren Fachwörterbüchern. Hoffmann, L. et al. (Reds.). 1999. Fachsprachen. Ein internationales Handbuch zur Fachsprachenforschung und Terminologiewissenschaft/ Languages for Special Purposes. An International Handbook of Special-Language and Terminology Research: 1762-1832. Berlyn: De Gruyter.

Claus, V. en A. Schwill. 19973. Schüler Duden: Informatik. Mannheim: Dudenverlag.

Cowie, A.P. (Red.). 1987. The Dictionary and the Language Learner. Tübingen: Max Niemeyer.

Dolezal, F.T. en D.R. McCreary. 1999. Pedagogical Lexicography Today. A Critical Bibliography on Learners' Dictionaries with Special Emphasis on Language Learners and Dictionary Users. Tübingen: Max Niemeyer.

Fuertes-Olivera, P.A. en A. Arribas-Baño. 2008. Pedagogical Specialised Lexicography. The Representation of Meaning in English and Spanish Business Dictionaries. Amsterdam/Philadelphia: John Benjamins.

Gouws, R.H. 2001. Lexicographic Training: Approaches and Topics/Formation lexicographique: approches et thèmes. Emejelu, J.D. (Red.). 2001. Éléments de lexicographie gabonaise. Tome I: 5894. New York: Jimacs-Hillman.

Gouws, R.H. 2005. Meilensteine auf dem historischen Weg der Metalexikographie. Lexicographica 21: $158-178$.

Gouws, Rufus H. 2007. A Transtextual Approach to Lexicographic Functions. Lexikos 17: 77-87.

Gouws, R.H. 2007a. Op pad na 'n nuwe woordeboektipologie. Southern African Linguistics and Applied Language Studies 25(3): 319-331.

Gouws, R.H. en P. Leroyer. 2009. Verhoogde leksikografiese toeganklikheid in die oorgang van ' $n$ toeristewoordeboek na 'n toeristegids as naslaanbron. Tydskrif vir Geesteswetenskappe 49(1): 145-149.

Gouws, R.H., M. Stark en L. Gouws. 2004. Nuwe woordeboek sonder grense. Kaapstad: Maskew Miller Longman.

Gouws, S. en M. Latti. 1996-2002. Nuwe Afrikaans sonder grense. Kaapstad: Maskew Miller Longman.

Gouws, S. en M. Latti. 2004. Nuwe woordeboek sonder grense Werkboek Gr. 4. Kaapstad: Maskew Miller Longman.

Gouws, S. en M. Latti. 2004. Nuwe woordeboek sonder grense Werkboek Gr. 6. Kaapstad: Maskew Miller Longman.

Gouws, S. en M. Latti. 2004 Nuwe woordeboek sonder grense Werkboek Gr. 5. Kaapstad: Maskew Miller Longman.

Gouws, S. en M. Latti. 2005 Nuwe woordeboek sonder grense Werkboek Senior Fase Gr. 7-9. Kaapstad: Maskew Miller Longman.

Hartmann, R.R.K. 1989. Sociology of the Dictionary User: Hypotheses and Empirical Studies. Hausmann, F.J. et al. (Reds.). 1989-1991. Wörterbücher. Ein internationales Handbuch zur Lexikographie/Dictionaries. An International Encyclopedia of Lexicography/Dictionnaires. Encyclopédie internationale de lexicographie: 102-111. Berlyn: De Gruyter.

Hartmann-Petersen, P. et al. 2001. SASOL Science and Technology Resource. Claremont: New Africa Education Publishing.

Hausmann, F.J. 1974. Was ist und was soll ein Lernwörterbuch? Zeitschrift für französische Sprache und Literatur 84: 97-129. 
Herbst, T. en K. Popp (Reds.). 1999. The Perfect Learners' Dictionary (?). Tübingen: Max Niemeyer.

Hiles, L. 2007. Oxford Tweetalige Werkboek/Workbook. Kaapstad. Oxford University Press.

Hornby, A.S. 1948. Oxford Advanced Learner's Dictionary. Oxford: Oxford University Press.

Ildokó, F. 2005. Ungarisch-Deutsches Deutsch-Ungarisches Fachwörterbuch zur Rentenversicherung. Szeged: Grimm Kiadó.

Kammerer, M. en H.E. Wiegand. 1998. Über die textuelle Rahmenstruktur von Printwörterbüchern. Präzisierungen und weiterführende Überlegungen. Lexicographica 14: 224-238.

Kaufmann, U. en H. Bergenholtz (Reds.). 1998. Encyclopedic Dictionary of Gene Technology/Diccionario Encyclopédico Ingeniaría Genética. Vol. I: English (With Spanish Equivalents); Vol. II: Español (Con equivalentes en inglés). Toronto: Lugus Libros Latin América.

Kipfer, B.A. 1984. Workbook on Lexicography: A Course for Dictionary Users with a Glossary of English Lexicographical Terms. Exeter: University of Exeter Press.

Kwiatkowski, G. (Red.). 19892. Schüler Duden: Die Musik. Mannheim: Dudenverlag.

Lochner, J. In voorbereiding. Woordeboek van Afrikaanse Geneeskundeterme. Kaapstad: Pharos.

Louw, P.A. (Red.). 2007. Oxford Afrikaans-Engels/English-Afrikaans Skoolwoordeboek/School Dictionary. Kaapstad: Oxford University Press.

Otto, A.N. 1989. Kriteria vir 'n Afrikaanse aanleerderwoordeboek. Ongepubliseerde D.Litt.-verhandeling. Stellenbosch: Universiteit van Stellenbosch.

Pyne, S. en A. Tuck. 1996. Oxford Dictionary of Computing for Learners of English. Oxford: Oxford University Press.

Schaeder, B. en H. Bergenholtz (Reds.). 1994. Fachlexikographie. Fachwissen und seine Repräsentation in Wörterbüchern. Tübingen: Gunter Narr.

Sinclair, J. (Red.). 1987. Collins COBUILD English Language Dictionary. Londen/Glasgow: Collins.

Stark, M.P. 1990. Dictionary Workbooks. A Critical Evaluation of Dictionary Workbooks for the Foreign Language Learner. Exeter: University of Exeter Press.

Steyn, M. 2004. The Access Structure in Learner's Dictionaries. Lexikos 14: 275-298.

Steyn, M. en L. Gouws. 2005. Nuwe Woordeboek sonder Grense: A Typological and Communicative Bridge. Lexikos 15: 164-178.

Takebayashi, S. en Y. Kojima (Reds.). 1990². Kenkyusha's Lighthouse English-Japanese Dictionary. Tokio: Kenkyusha.

Tarp, S. 2000. Theoretical Challenges to Practical Specialised Lexicography. Lexikos 10: 189-208.

Tarp, S. 2008. Lexicography in the Borderland between Knowledge and Non-Knowledge. General Lexicographical Theory with Particular Focus on Learner's Lexicography. Tübingen: Max Niemeyer.

Wiegand, H.E. (Red.). 1998. Perspektiven der pädagogischen Lexikographie des Deutschen. Untersuchungen anhand von Langenscheidts Großwörterbuch Deutsch als Fremdsprache. Tübingen: Max Niemeyer.

Wiegand, H.E. 1998a. Wörterbuchforschung. Untersuchungen zur Wörterbuchbenutzung, zur Theorie, Geschichte, Kritik und Automatisierung der Lexicographie. 1. Teilband. Berlyn: De Gruyter.

Wiegand, H.E. (Red.). 2002. Perspektiven der pädagogischen Lexikographie des Deutschen II. Untersuchungen anhand des de Gruyter Wörterbuch Deutsch als Fremdsprache. Tübingen: Max Niemeyer.

Wiegand, H.E. et al. (Reds.). 2009. Fachwörterbuch zur Lexikographie und Wörterbuchforschung/ Dictionary of Lexicography and Dictionary Research. Berlyn: De Gruyter.

Woordeboek van die Afrikaanse Taal. Stellenbosch: Buro van die WAT. 